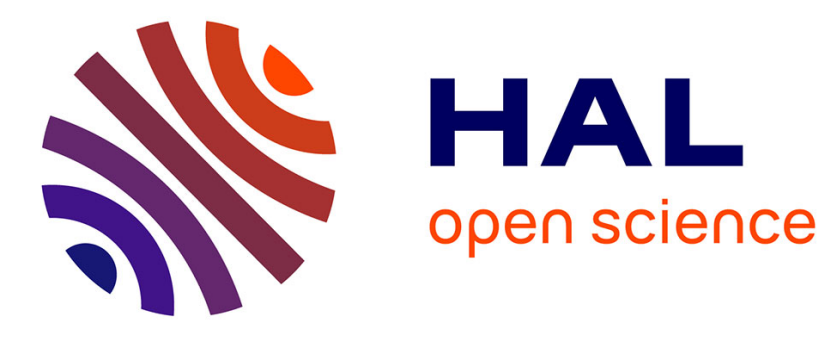

\title{
Mineralogical composition of aerosols at Amsterdam Island
}

\author{
A. Gaudichet, R. Lefèvre, A. Gaudry, B. Ardouin, G. Lambert, J. Miller, A \\ Gaudichet', R Lefevre', A Gaudryz, B Ardouinz, et al.
}

\section{- To cite this version:}

A. Gaudichet, R. Lefèvre, A. Gaudry, B. Ardouin, G. Lambert, et al.. Mineralogical composition of aerosols at Amsterdam Island. Tellus B - Chemical and Physical Meteorology, 1989, 41B (3), pp.344-352. 10.1111/j.1600-0889.1989.tb00313.x . hal-03554864

\author{
HAL Id: hal-03554864 \\ https://hal.science/hal-03554864
}

Submitted on 3 Feb 2022

HAL is a multi-disciplinary open access archive for the deposit and dissemination of scientific research documents, whether they are published or not. The documents may come from teaching and research institutions in France or abroad, or from public or private research centers.
L'archive ouverte pluridisciplinaire HAL, est destinée au dépôt et à la diffusion de documents scientifiques de niveau recherche, publiés ou non, émanant des établissements d'enseignement et de recherche français ou étrangers, des laboratoires publics ou privés. 


\title{
Mineralogical composition of aerosols at Amsterdam Island
}

\author{
By A. GAUDICHET ${ }^{1}$, R. LEFÈVRE 1 , A. GAUDRY², B. ARDOUIN ${ }^{2}$, G. LAMBERT ${ }^{2}$ \\ and J. M. MILLER', 'Laboratoire de Microscopie Analytique Appliquée aux Sciences de la Terre, \\ Université Paris XII, 94010 Créteil, France; ${ }^{2}$ Centre des Faibles Radioactivités Laboratoire mixte \\ CNRS/CEA, 91198 Gif/Yvette Cedex, France; ${ }^{3}$ Air Resources Laboratory, 20910 Silver Spring, \\ Maryland, USA
}

(Manuscript received 28 December 1987; in final form 3 October 1988)

\begin{abstract}
In this paper, data on the mineralogical composition of insoluble particulate matter collected in May, July and September 1984 at Amsterdam Island, South Indian Ocean $\left(34^{\circ} 47^{\prime} S\right.$, $\left.77^{\circ} 31^{\prime} \mathrm{E}\right)$ are presented for the first time. Atmospheric levels of these insoluble aerosols remain very low (from 0.25 to $0.01 \mu \mathrm{g} \mathrm{m}^{-3}$ ); the size of the particles is mainly in the submicronic range. The long-range continental origin of these particles is well confirmed by atmospheric tracers such as ${ }^{222} \mathrm{Rn}$ and ${ }^{210} \mathrm{~Pb}$ and by air mass back-trajectories. Continental inputs, mainly from South Africa and Madagascar, that can be identified by "radonic storms" have a high illite/kaolinite ratio. However those from Australia, though less frequent at Amsterdam Island, have a low illite/kaolinite ratio. Thus, kaolinite can be considered a good tracer of transport of Australian aerosols into the subantarctic.
\end{abstract}

\section{Introduction}

The distribution and composition of the marine dust veil have been documented for the Atlantic and Pacific oceans and the Mediterranean Sea (Chester, 1986). In the South Indian Ocean, no data are available, except for a few atmospheric dust samples collected close to South Africa and Madagascar (Aston et al., 1973). In this preliminary study we present for the first time data on the mineralogical composition of aerosols collected in the middle of the Indian Ocean, at Amsterdam Island.

Furthermore, these mineralogical characteristics are tentatively categorized according to the origins of the particles, as has been done in previous studies (Prospero et al., 1981; Gaudichet and Buat Menard, 1982; Paquet et al., 1984). These sources, either continental (soil dust, volcanic, anthropogenic) or marine, can be confirmed by the study of air mass back-trajectories, as well as by the content of the natural radio- active nuclides $\mathrm{Rn}-222$ and $\mathrm{Pb}-210$. These two nuclides, which are generally held to be continental in origin, were continuously measured during aerosol samplings.

Because of the low concentration of mineral matter over the remote open ocean, the Analytical Transmission Electron Microscopy (ATEM) technique was used as the most appropriate method of analysis instead of X-ray analysis, which requires large amounts of material.

\section{Sampling}

Amsterdam Island, Territoire des Terres Australes et Antarctiques Françaises (TAAF), is located at $37^{\circ} 47^{\prime} \mathrm{S}, 77^{\circ} 31^{\prime} \mathrm{E}$ (Fig. 1), in the prevailing westerlies. Because of its remote position, the island is particularly well suited for measuring the background concentrations of various atmospheric constituents. It is $5000 \mathrm{~km}$ from the African and Australian continents. 


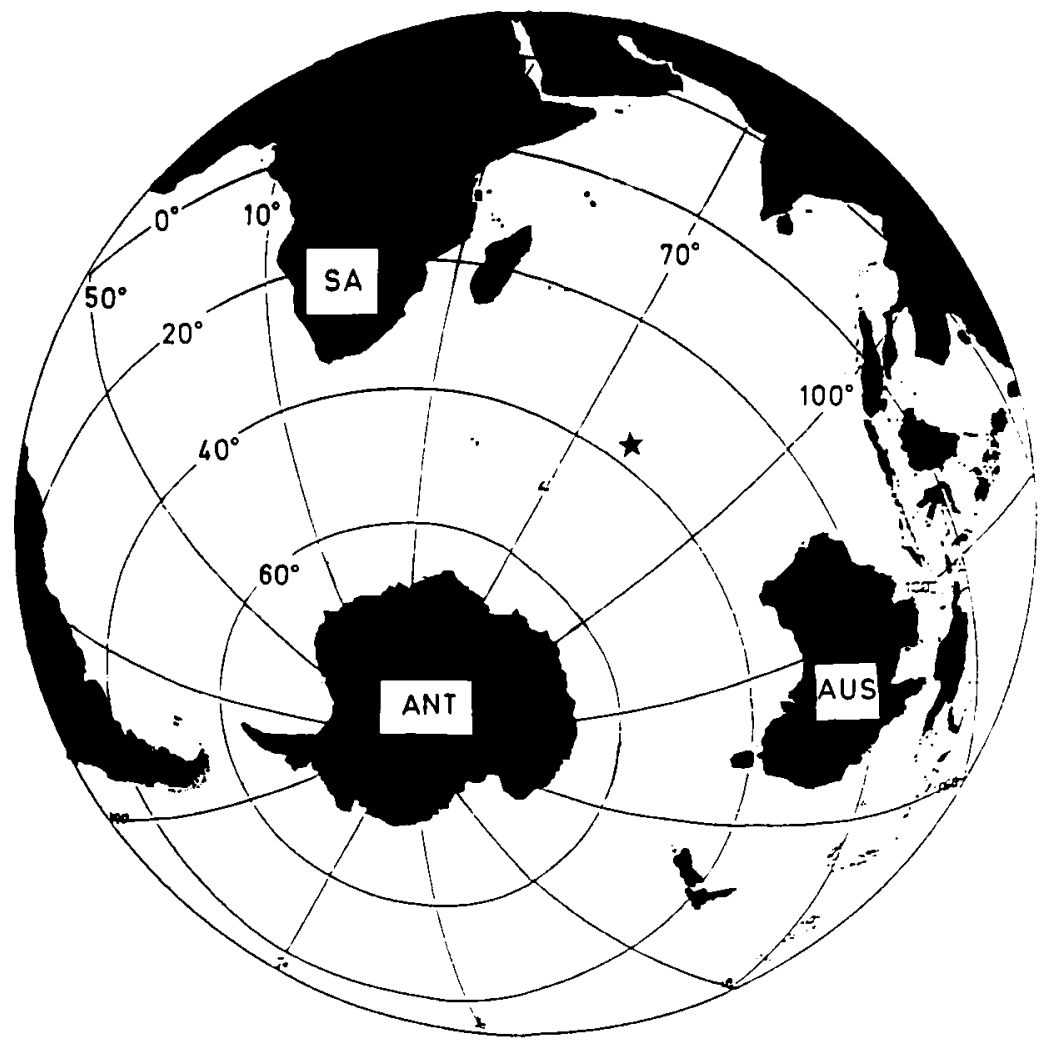

Fig. 1. Location of Amsterdam Island ( $\star$ ) in the Indian Ocean (SA: South Africa; Aus: Australia; Ant: Antarctica.

Ocean traffic is extremely scarce, limited to a few ships per year for the relief and re-supply of the island's scientific team, about 35 members, who are the only inhabitants of the island. No sampling was undertaken during the stay of these ships.

The samples were collected at Pointe Benedicte (Fig. 2), a north-facing cape $2.5 \mathrm{~km}$ away from the base, on a $9 \mathrm{~m}$-high aluminium tower built at the edge of a $55-\mathrm{m}$ cliff. Around the tower, the soil is covered with graminea. In addition, the wind blows directly from the sea, without crossing the island, in an oceanic sector between $280^{\circ}$ and $040^{\circ}$ (clockwise).

$\mathrm{CO}_{2}$ has been monitored at the same place since 1980. Gaudry et al. (1983) have shown that when wind blows from the marine sector at speeds faster than $5 \mathrm{~m} \mathrm{~s}^{-1}$, the influence of the island vegetation on $\mathrm{CO}_{2}$ concentrations is not detectable. But when air comes from the other sector, the $\mathrm{CO}_{2}$ concentrations have standard deviations up to $1.75 \mathrm{ppmv}$, indicating the local influence of the island. During this study, aerosols were collected only when the flow was from the marine sector.

The aerosols were collected by filtration at a $1 \mathrm{~m}^{3} \mathrm{~h}^{-1}$ flow rate. The sampling heads "Millipore ${ }^{\circledR}$ Aerochecks" were fitted with a Nucleopore ${ }^{\text {(i) }}$ membrane of $0.45 \mu \mathrm{m}$ in porosity and $37 \mathrm{~mm}$ in diameter. The Aerochecks were shielded from the rains. Since their inlet diameter is only $3 \mathrm{~mm}$, no particle were collected when the pumping was switched off; this was particularly true during rainy weather.

For sampling the following protocol was used:

(1) scrolled, torn, or damaged filters were discarded;

(2) the remote continental influence was estimated to be high (sample 1), moderate (sample 2 ), or low (sample 3) when compared to the corresponding values of the radionuclides (see further).

Tellus 41B (1989), 3 


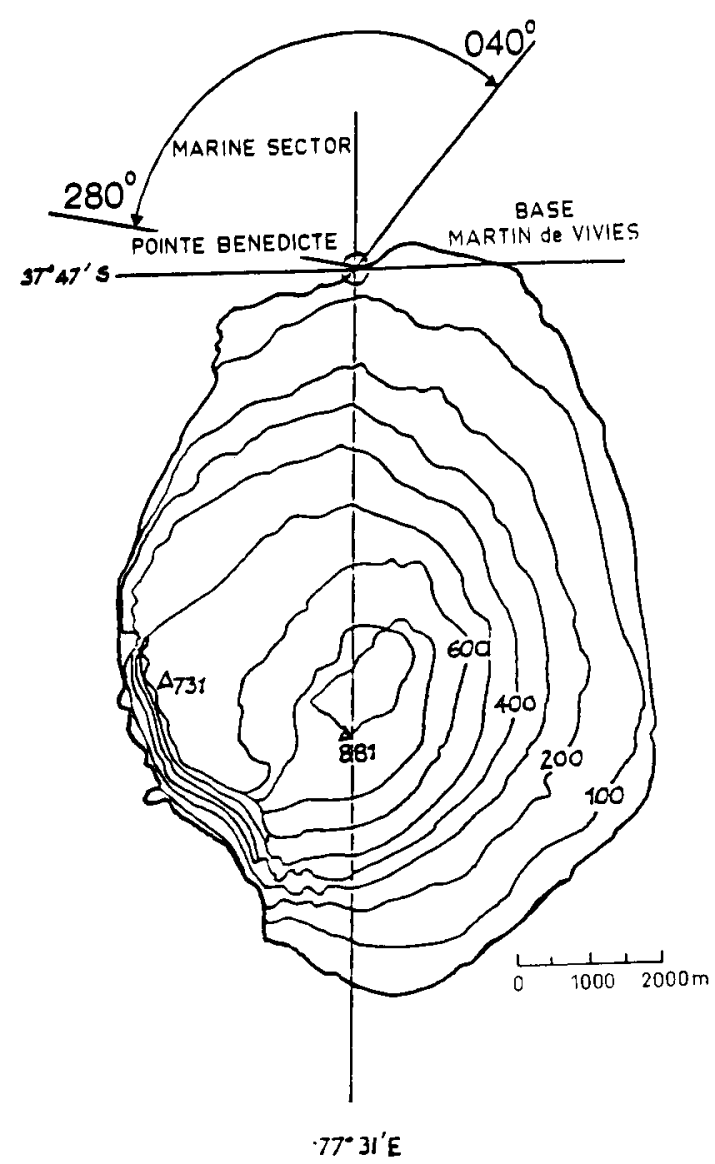

Fig. 2. Map of Amsterdam Island and location of the sampling site.

The sampling period was allowed to be as long as possible and was only stopped when the filter was clogged by marine aerosols due to sea spray, that is when the flow rate was reduced to half of its initial value. The sampling periods averaged about 2 to 3 weeks. However, as we selected only winds from the marine sector, the actual pumping times for the May, July, and September samples were 18,7 , and $24 \%$ respectively of the total time of exposure of the filters.

\section{Particle analysis}

The total particle loading on a filter includes soluble (SP) and insoluble (IP) particles of which sea salt contributes up to $99.5 \%$ of the particle count. This required washing the filters to extract the IP; the filter was submerged in distilled, prefiltered water and treated with ultrasonic vibrations for five minutes to extract particles from the membrane surface and the flask walls. The particulate matter, recovered in the washing liquid, was then concentrated by filtration through a Nucleopore ${ }^{\mathbb{Q}}$ membrane $(0.2 \mu \mathrm{m}$ in porosity and $25 \mathrm{~mm}$ in diameter), which was previously carbon coated. This technique has a negligible particle loss as demonstrated by Sebastien et al. (1978). Thus, particles deposited on the surface membrane were subsequently coated with a second carbon layer and transferred directly onto gold Transmission Electron Microscope grids by dissolving under suction the membrane substrate with chloroform. This preparation was applied to the washed and blank membranes, in order to check the efficiency of the washing and the transfer procedure.

The mineralogical analysis was performed under a Transmission Electron Microscope JEOL $100 \mathrm{C}$, fitted with a chemical microanalysis system (Energy Dispersive Spectrometer of X-Rays: EDAX 711). Particles were individually identified using a step by step process:

morphological features (until $0.02 \mu \mathrm{m}$ );

electron diffraction patterns enabling to distinguish amorphous from cristalline particles, and among the second ones, sheet silicates;

the semi-quantitative assessment of their elemental chemical composition using the peak ratio method (Cliff and Lorimer, 1975) for elements with an atomic number greater than 10 .

The analytical strategy consists in identifying, counting, and sizing each particle encountered in randomly chosen areas of a known surface (Gaudichet et al., 1986). Since this method is very time consuming, we have tested in a previous work the reliability of such counts on 100 particles (Buat-Ménard et al., 1983). This permits the determination of :

the total particle number per cubic meter of air;

a mean encircled diameter of individual particle images;

the relative frequency of each mineral species.

\section{Results and discussion}

\subsection{Mineralogy}

The sea salts consist mainly of chlorides (halite) and magnesium or sodium sulfates and 

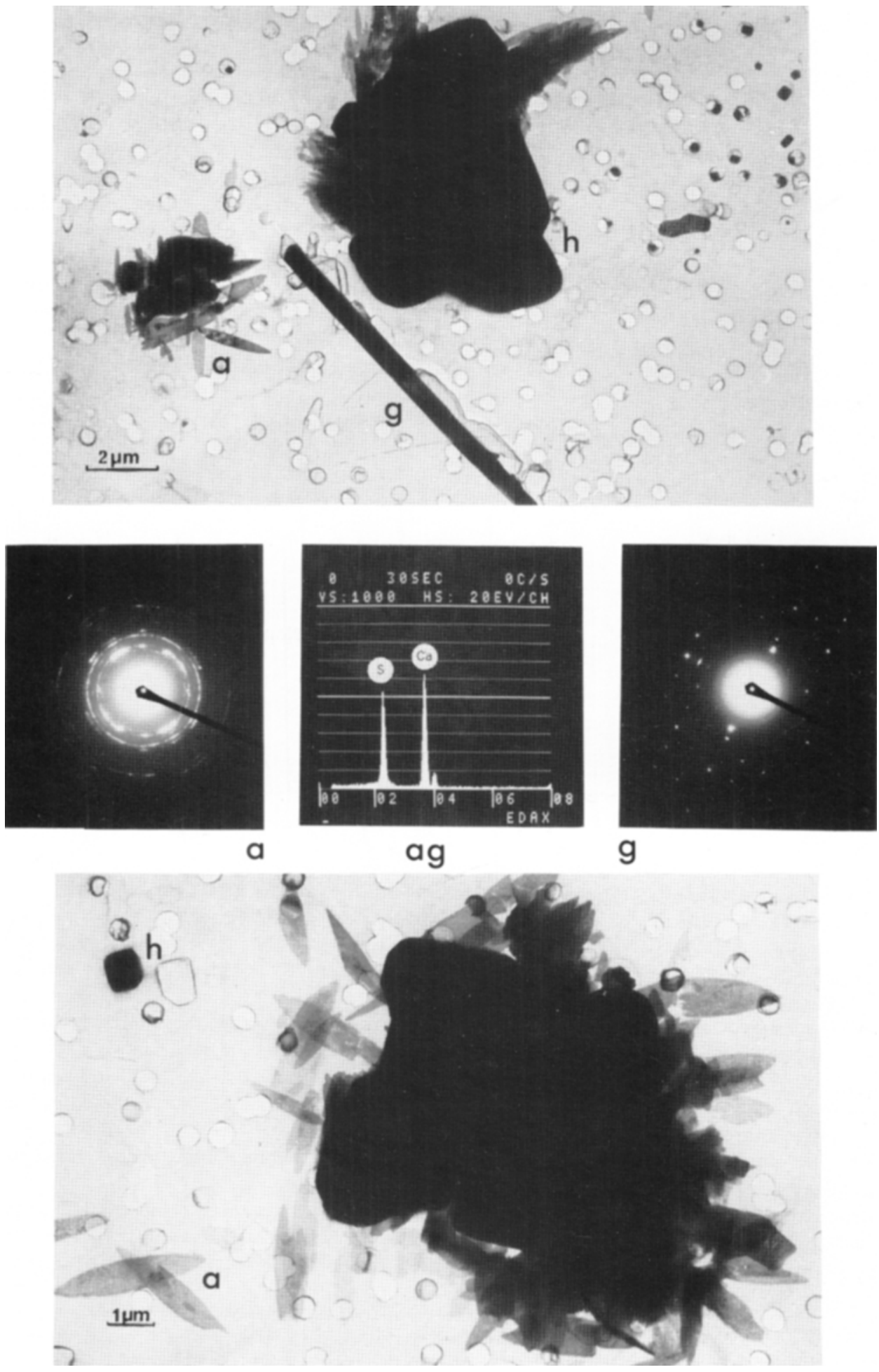
a

ag

g

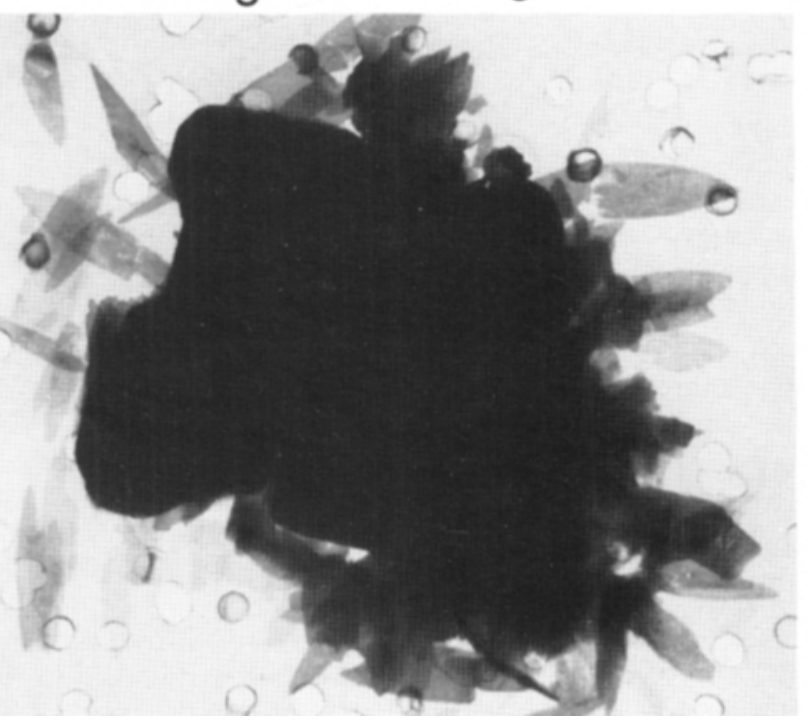

Tellus 41 B (1989), 3 
Table 1. Insoluble mineral microparticles identified in 3 air samples collected at Amsterdam Island: different species (number and percentage), mean concentrations and mean size

\begin{tabular}{|c|c|c|c|}
\hline $\begin{array}{l}\text { Period } \\
\text { Volume }\left(\mathrm{m}^{3}\right)\end{array}$ & $\begin{array}{l}\text { Sample } 1 \\
15 \text { to } 26 \text { May } \\
44\end{array}$ & $\begin{array}{l}\text { Sample } 2 \\
7 \text { to } 30 \text { July } \\
30\end{array}$ & $\begin{array}{l}\text { Sample } 3 \\
5 \text { to } 29 \text { Sept. } \\
82\end{array}$ \\
\hline & \multicolumn{3}{|c|}{ No. different species and $(\%)$} \\
\hline cristalline silica & $5 \quad(4)$ & $7 \quad(8)$ & $4 \quad(4)$ \\
\hline muscovite-illite & $21 \quad(16)$ & $6 \quad(7)$ & $7 \quad(7)$ \\
\hline kaolinite & $10 \quad(8)$ & $4 \quad(4)$ & 16 (17) \\
\hline smectites & $8 \quad(6)$ & -- & - \\
\hline chlorites-talc & $1 \quad(1)$ & $1 \quad(1)$ & $3 \quad(3)$ \\
\hline feldspars & $6 \quad(4)$ & -- & 2 (2) \\
\hline unidentified silicates & 12 (9) & $5 \quad(5)$ & $6 \quad(6)$ \\
\hline amorphous silica & $10 \quad(8)$ & $25(27)$ & $7 \quad(7)$ \\
\hline calcium compounds & -- & $1 \quad(1)$ & $1 \quad(1)$ \\
\hline fly-ash & $7 \quad(6)$ & $1 \quad(1)$ & $-\ldots$ \\
\hline $\begin{array}{l}\text { agglomerated spheres } \\
\text { metallic grains: }\end{array}$ & $30 \quad(22)$ & $18 \quad(20)$ & $1 \quad(1)$ \\
\hline $\mathrm{Fe} / \mathrm{Fe}-\mathrm{Cr}-\mathrm{Ni} / \mathrm{Cr}$ & $5 \quad(3)$ & $5 \quad(6)$ & $8 \quad(8)$ \\
\hline $\mathrm{Ti} / \mathrm{Fe}-\mathrm{Ti}$ & $1 \quad(1)$ & $6 \quad(6)$ & $25(26)$ \\
\hline $\mathrm{Sn}$ & $1 \quad(1)$ & 13 (14) & -- \\
\hline Al-(Cl-S) & -- & -- & $10(11)$ \\
\hline $\mathrm{C}$ chained microspheres & $15(11)$ & $-\quad-$ & 7 (7) \\
\hline Total analyzed & $132(100)$ & $92(100)$ & $97(100)$ \\
\hline \multicolumn{4}{|l|}{${ }^{*}$ Concentrations } \\
\hline (number $\cdot \mathrm{m}^{-3}$ & $3 \times 10^{5}$ & $10^{5}$ & $2.6 \times 10^{4}$ \\
\hline$\left.\mu \mathrm{g} \mathrm{m}^{-3}\right)$ & 0.25 & 0.05 & 0.01 \\
\hline $\begin{array}{l}\text { *Mean size } \\
\quad(\mu \mathrm{m} \text { and }(\mathrm{std}))\end{array}$ & $0.9(0.8)$ & $0.7(0.5)$ & $0.7(1)$ \\
\hline
\end{tabular}

* Values calculated for total particles except $\mathrm{C}$ chained microspheres.

minor amounts of calcium sulfates (gypsum or anhydrite) (Fig. 3). A total of 321 IP were analysed for the three selected samples. Results are reported in Table 1.

If we exclude chained carbonaceous microspheres (which are individually around $0.02 \mu \mathrm{m}$ ), the size of IP ranges from 0.3 to $4 \mu \mathrm{m}$, with a mean size of $0.9( \pm 0.8), 0.7( \pm 0.5)$, and $0.7( \pm 1)$ $\mu \mathrm{m}$ for samples 1,2 and 3 respectively. The IP atmospheric concentration expressed in $10^{5}$ particles per $\mathrm{m}^{3}$ is 3,1 , and only 0.3 in samples 1,2 , and 3 respectively.

A mass concentration $C_{\mathrm{m}}$ can also be calculated, by using the number of particles, a representative density (silicate $2.6 \mathrm{~g} \mathrm{~cm}^{-3}$ ) and the radius of the mean circle circumscribing the particles. Then $C_{\mathrm{m}}$ is $0.25,0.05$, and $0.01 \mu \mathrm{g} \mathrm{m}^{-3}$ in samples 1,2 , and 3 , respectively. These values are quite similar to the atmospheric dust concentrations determined for "clean seasons" (with the lowest transport of dust) at the sampling stations of the SEAREX Asian dust network in the Pacific Ocean (Uematsu et al., 1985) and confirm the reduction of the dust veil in this South Indian Ocean area.

Mineral species can tentatively be related to their origin:

- Marine biogenic particles represent 8, 28, and $8 \%$ in samples 1,2 and 3, respectively. They are mainly amorphous silica (Radiolaria or diatom

Fig. 3. Transmission electron micrographs, electron diffraction patterns and energy dispersive X-ray spectrum of soluble particles collected at Amsterdam Island; (a) anhydrite; (g) gypsum; (h) halite. 

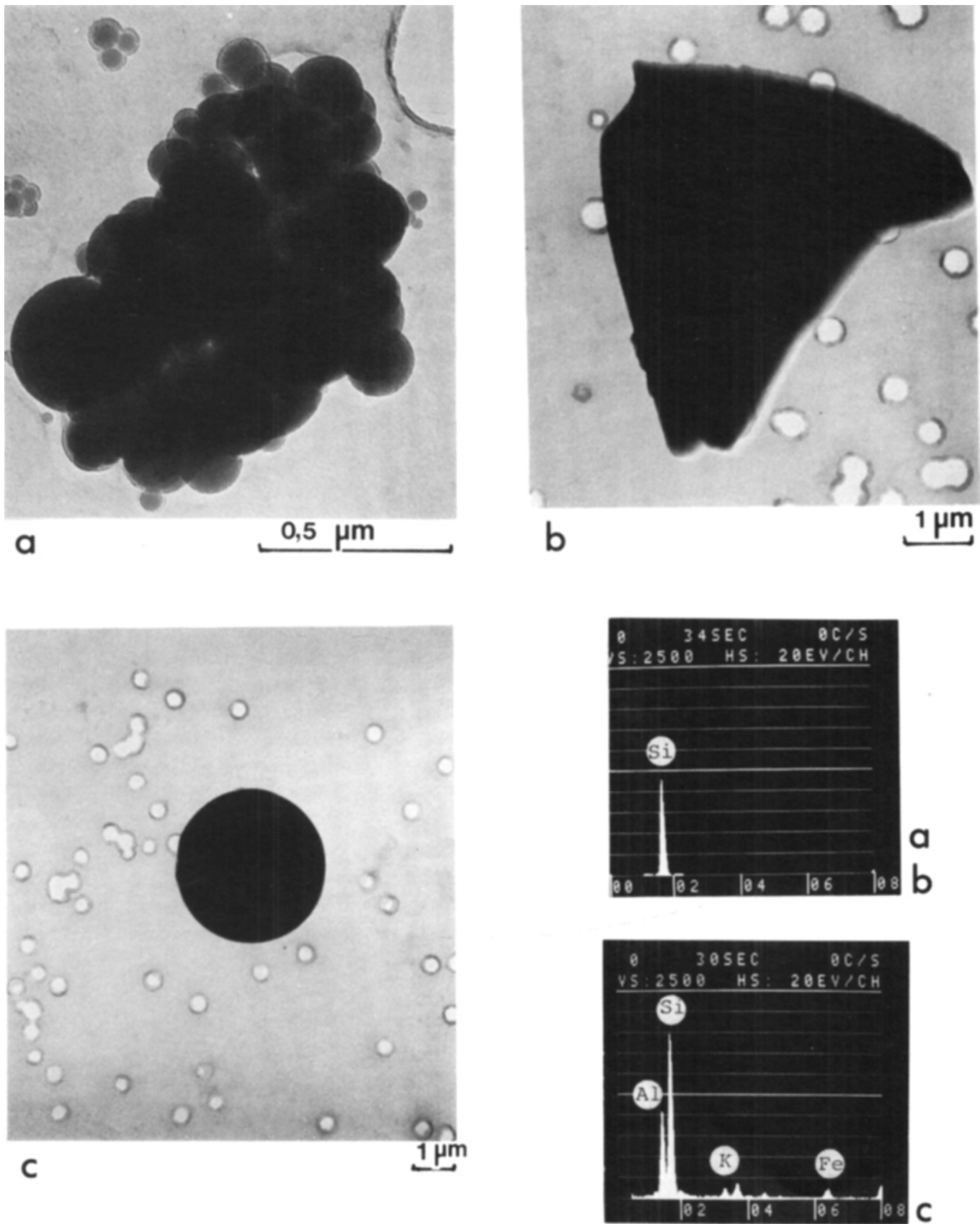

Fig. 4. Transmission electron micrographs, and energy dispersive X-ray spectra of insoluble microparticles collected at Amsterdam Island; (a) Si-rich agglomerated spheres; (b) angulous grain of amorphous silica; (c) typical industrial fly-ash. 
fragments; see Fig. 4) and to a lesser degree calcium compounds (possibly carbonates).

- Anthropogenic particles are of three types: the first consists of typical spherical fly ash ( $\mathrm{Si}-\mathrm{Al}$ as major elements; see Fig. 4) representing melted mineral residues of coal burning; they are mainly present in sample 1. Among agglomerated spheres (see Table 1), those consisting of $\mathrm{Fe}$ or Sn, represent probably welded fume condensates. Metallic angular grains containing uncommon natural elements such as $\mathrm{Sn}$ or $\mathrm{Cr}$ can be also considered as typical anthropogenic components. For some particles, their origin, natural and/or anthropogenic, remains ambiguous:

All angular $\mathrm{Fe}$ or $\mathrm{Ti}$, or $\mathrm{Fe}-\mathrm{Ti}$ compounds represent natural oxides, currently present as minor minerals in rocks, but largely used for various industrial applications.

The Si agglomerated spheres (the most abundant; see Fig. 4) have been described as industrial condensates or as volcanic products (Lefèvre et al., 1982).

The Al products could be related to natural oxides or hydroxides; some of them (Gibbsite and Boehmite) are currently associated with kaolinite in lateritic soils. Moreover, Al compounds have been also described as rocket exhausts (Clantone et al., 1982). The $\mathrm{Cl}$ and/or $\mathrm{S}$ association with $\mathrm{Al}$, observed in some particles as minor elements, cannot be explained at the present time.

The chained microspheres without chemical response under electron beam excitation are likely composed of light elements (atomic number smaller than 11). They are well known as diesel exhaust products ("microsoots") (Marduel et al., 1987) but could also represent biomass products (Cachier et al., 1986).

- Very common natural terrigeneous silicates represent $48 \%$ of the IP in the first sample, $25 \%$ in the second, and $39 \%$ in the third. They consist of silicates, such as quartz, muscovite-illite, kaolinite, smectites, chlorites, talc, feldspars, and other unidentified silicates.

Regarding the continental aeolian dust source regions, from which clays classically originated, our samples can only be characterized by comparing kaolinite (K) and illite (I) concentrations, because of the small amounts of other silicates such as chlorites, talc, and smectites. In effect, illite is a globally widespread clay species, whereas kaolinite is more common in Australian soils (Butler, 1974) and in recent marine sediments around this continent (Griffin et al., 1986). Therefore, kaolinite can be considered as a good tracer of terrigeneous Australian dust transport.

It can be pointed out that the $I / K$ ratios are very different in sample $1(I / K=2.1$; standard deviation is 0.8$)$ and in sample $3(I / K=0.4$; standard deviation is 0.18). Despite the small number of $I$ and $K$ particles counted, this difference is high enough to be significant. Moreover, it has been possible to relate the compositions of these samples to the back-trajectories of the corresponding air masses, and their contents in continental ${ }^{222} \mathrm{Rn}$, and ${ }^{210} \mathrm{~Pb}$ tracers.

\subsection{Back-trajectories}

The isobaric ten-day back-trajectories of air masses arriving at Amsterdam Island, at 00 and $12 \mathrm{~h} \mathrm{GMT}$ were constructed at 700 and $850 \mathrm{HP}$.

The aerosols of sample 1 were collected on 19 to 21, 23, and 24 May. During this sampling, it can be observed that the air masses originated either from the Indian Ocean (without crossing over any continent) or from South Africa (on 19, 21 , and 24 May).

The aerosols of sample 2 were collected on 6 to $8,10,11,16,17,20,21,25,26,28,29$ July. Corresponding air masses originated either from the Indian Ocean or from South Africa or Madagascar (on 8 and $17 \mathrm{July}$, and on 6, 8, and 16 July, respectively).

The aerosols of sample 3 were collected on 5 to $9,11,14,19$ to 24 September. Beyond the preceding air mass origins, we observed on 19, 20, 22, and 24 September air masses originating off the western Australian coast. It is worth noting that such an occurrence is rather seldom at Amsterdam Island.

\subsection{Natural radioactivity}

4.3.1. Radon 222. The 3.8-day half-life ${ }^{222} \mathrm{Rn}$ is a decay product of ${ }^{226} \mathrm{Ra}$. It is injected into the atmosphere from the free surface of continents and transported over oceans, which are not a radon source. Thus, the ${ }^{222} \mathrm{Rn}$ variations are related to an atmospheric terrigeneous input. This long-range transport has been well documented by G. Polian et al. (1986), who attributed ${ }^{222} \mathrm{Rn}$ high concentrations (called "radonic storms") mainly to South Africa or Madagascar, 
and to a lesser extent to South America. When low-velocity winds cross the island, atmospheric ${ }^{222} \mathrm{Rn}$ may have a local origin. Measurements of ${ }^{212} \mathrm{~Pb}$ (a decay product of the short half-life radionuclide ${ }^{220} \mathrm{Rn}$, considered a tracer of the local influence of the island) confirm that any local ${ }^{22} \mathrm{Rn}$ input can be considered as negligible during our sampling periods.

${ }^{222} \mathrm{Rn}$ was monitored at Amsterdam Island every $2 \mathrm{~h}$ according to the method described by Lambert et al. (1972). To determine the importance of the continental influence in our samples, we calculated in Table 2 an average ${ }^{222} \mathrm{Rn}$ radioactivity $(R)$, corresponding to the real duration of the aerosol collections, above the mean oceanic background $\left(0.5 \mathrm{pCi} \mathrm{m}^{-3}\right)$. Thus, it can be observed that sample 1 is the most influenced by a recent influx of continental ${ }^{222} \mathrm{Rn}$, for which two clear "radonic storms" were observed on 19 May $\left(7 \mathrm{pCi} \mathrm{m}^{-3}\right)$ and 21 May $\left(6 \mathrm{pCi} \mathrm{m}^{-3}\right)$. Sample 2 is less strongly influenced, marked only by one "radonic storm" on 16 and 17 July $\left(5 \mathrm{pCi} \mathrm{m}^{-3}\right)$, and periods with lower but above-background radon concentrations. The sample 3 was the least influenced (6 times less than sample 1) with ${ }^{222} \mathrm{Rn}$ concentration levels always less than $3 \mathrm{pCi} \mathrm{m} \mathrm{m}^{-3}$. For this sample, when the back-trajectories passed near the western Australian coast, no ${ }^{222} \mathrm{Rn}$ was measured, indicating that if an Australian input did occur, as shown by particular back-trajectories, it corresponds to old or highly diluted Australian air masses.

\section{Table 2}

Column $A$. Integrated mean concentration of ${ }^{222} \mathrm{Rn}$ during the real pumping period

Column $B .{ }^{210} \mathrm{~Pb}$ radioactivity in desintegrations per minute and per $\mathrm{m}^{3}$ on samples collected during the total sampling period

Column $C$. Monthly mean concentration of the ${ }^{21} \mathrm{~Pb}$, respectively, on May, July and September 1984

\begin{tabular}{llll}
\hline Sample & $\begin{array}{l}\text { (A) } \\
\mathrm{pCi} \mathrm{m}^{-3}\end{array}$ & $\begin{array}{l}\text { (B) } \\
\mathrm{dpm} \mathrm{m} \mathrm{m}^{-3}\end{array}$ & $\begin{array}{l}\text { (C) } \\
\mathrm{dpm} \mathrm{m} \mathrm{m}^{-3}\end{array}$ \\
\hline 1 & 1.75 & $2.5 \times 10^{-3}$ & $0.7 \times 10^{-3}$ \\
2 & 1.11 & $3.6 \times 10^{-3}$ & $1.2 \times 10^{-3}$ \\
3 & 0.32 & $1.2 \times 10^{-3}$ & $1.4 \times 10^{-3}$ \\
\hline
\end{tabular}

4.3.2. Lead 210. This radionuclide is a daughter product of ${ }^{222} \mathrm{Rn}$ and has a 20 -year halflife. It is fixed on submicronic particles (Sanak et al., 1983). This tracer integrates the remote continental influence (Turekian et al., 1981). ${ }^{210} \mathrm{~Pb}$ is measured on filters sampled during one day, according to a method described by Lambert et al. (1988).

${ }^{210} \mathrm{~Pb}$ radioactivities appear also in Table 2. The results confirm, in samples 1 and 2 , the existence of a continental influence that is significantly higher continental influence than that in sample 3.

\section{Conclusion}

This paper gives a first description of the mineralogical composition of the insoluble component of aerosols in subantarctic areas. The major conclusion that there is a very small amount of insoluble particles in this atmosphere: less than $3 \cdot 10^{5} \mathrm{~m}^{-3}$ corresponding to a mass concentration ranging from 0.01 to $0.25 \mu \mathrm{g} \mathrm{m}^{-3}$. These particles, generally submicronic, which permits long-range transport from remote continents, marked by both a natural and an anthropogenic contribution.

The continental origin of these particles is well confirmed by atmospheric tracers $\left({ }^{222} \mathrm{Rn}\right.$ and $\left.{ }^{210} \mathrm{~Pb}\right)$ and by air mass back-trajectories, which showed that the aerosols are coming mainly from South Africa and/or Madagascar.

It can be pointed out that the ratios illite/ kaolinite vary significantly from sample to sample. The lowest value was related to a possible contribution of Australian dust. Such a signature of an Australian component in aerosols, kaolinite, could play a prominent part in future studies of antarctic dusts.

\section{Acknowledgements}

This work was supported by the "Ministère de l'Environnement" and by the "Territoire des Terres Australes et Antarctiques Françaises". We are grateful to the scientific team at Amsterdam Island who carried out the collection of the aerosols. 


\section{REFERENCES}

Aston, S. R., Chester, R., Johnson, L. R. and Padgham, R. C. 1973. Eolian dust from the lower atmopshere of the eastern Atlantic and Indian Oceans, China Sea and Sea of Japan. Marine Geology 14, 15-28.

Buat-Ménard, P., Ezat, U. and Gaudichet, A. 1983. Size distribution of mineralogy of alumino-silicates dust particles in Tropical Pacific air and rain. In: Precipitation, scavenging, dry deposition and resuspension (ed. H. R. Pruppacher et al.). New York: Elsevier Science Publishing, 1259-1269.

Butler, B. E. 1974. A contribution towards the better specification of parna and some other aeolian clays in Australia. Z. Geomorph. Suppl. Bd 20, 106-116.

Cachier, H., Buat-Mènard, P., Fontugne, $M$. and Chesselet, R. 1986. Long-range transport of continentally derived particulate carbon in the marine atmosphere: evidence from stable carbon isotope studies. Tellus 38B, 161-177.

Chester, R. 1986. The marine mineral aerosol. In: The role of air-sea exchange in geochemical cycling (ed. P. Buat-Ménard). Dordrecht: D. Reidel Publishing Company, 443-476.

Clanton, U. S., Gabel, E. M., Gooding, J. L., Isaacs, A. M., Mackinnon, I. D. R., Mackay, D. S., Nace, C. A. and Warren, J. L. 1982. Cosmic dust Catalog, Vol. 3, 1. Houston: Lyndon B. Johnson Space Center.

Cliff, G. and Lorimer, G. W. 1975. The quantitative analysis of thin specimens. J. Microsc. 103, 203-207.

Gaudichet, A. and Buat-Ménard, P. 1982. Mineralogy and origin of atmospheric particles over the Tropical North Pacific (Enewetak Atoll) by analytical transmission electron microscopy (in French). Compterendus de l'académie des Sciences 294, 1241-1246.

Gaudichet, A. and Buat-Ménard, P. 1982. Mineralogy and origin of atmospheric particles over the Tropical North Pacific (Enewetak Atoll) by analytical transmission electron microscopy (in French). Compterendus de l'académie des Sciences 294, 1241-1246.

Gaudry, A., Ascensio, J. M. and Lambert, G. 1983. Preliminary study of $\mathrm{CO}_{2}$ variations at Amsterdam Island (Territoire des Terres Australes et Antarctiques Françaises). J. of Geoph. Res. 88, 13231329.

Griffin, R. J., Windom, H. and Goldberg, E. D. 1968. The distribution of clay minerals in the world ocean. Deep Sea Res. 15, 433-459.
Lambert, G., Ardouin, B., Polian, G. and Sanak, J. 1972. Natural radioactivity balance in the atmosphere of southern hemisphere. In: Natural radiation environment 2, US Energy Research and Development Administration Conf. 720805 P2, 787-807.

Lambert, G., Ardouin, B., Polian, G. and Sanak, J. 1988. ${ }^{210} \mathrm{~Pb}$ transports over the subantarctic areas. Conference on the French research in the French Austral territories (in French). Comité National Français des Recherches Antarctiques, in press.

Lefèvre, R., Gaudichet, A. and Billon-Galland, M. A. 1986. Silicate microspherules intercepted in the plume of Etna volcano. Nature 322, 817-820.

Marduel, J. L., Boulaud, D. and Gaudichet, A. 1987. Diesel exhausts: regulated pollutants-particles (in French). Proceedings of the Colloque on the atmospheric pollution by the transports, Paris Juin 1987, INRETS ed. Arcueuil, France, 63-75. (Obtainable from Air Quality Agency, Tour GAN, Cedex 13, 92032 Paris la Défense, France.)

Paquet, H., Coude-Gaussen, G. and Rognon, P. 1984. Mineralogical data about desert dusts along a Saharan transect from latitude $19^{\circ}$ to $35^{\circ} \mathrm{N}$ (in French). Rev. Geol. Dyn. et Geogr. Phys. 25, 257-265.

Polian, G., Lambert, G., Ardouin, B. and Jegou, A. 1986. Long-range transport of continental radon in subantarctic and antarctic areas. Tellus 38B, 178-189.

Prospero, J. M., Glaccum, R. A. and Nees, R. T. 1981. Atmospheric transport of soil dust from Africa to South America. Nature 289, 270-281.

Sanak, J., Gaudry, A. and Lambert, G. 1981. Size distribution of ${ }^{210} \mathrm{~Pb}$ aerosols over oceans. G. Res. Lett. 8, 1067-1069.

Sebastien, P., Billon-Galland, M. A., Janson, X., Bonnaud, G. and Bignon, J. 1978. The use of transmission electron microscopy (TEM) for study of asbestos contamination (in French). Arch. Mal. Prof. 39, 229-248.

Turekian, K. K. and Cochran, J. K. 1981. ${ }^{210} \mathrm{~Pb}$ in surface air at Enewetak and the Asian dust flux to the Pacific. Nature 292, 522-524. (Corrigenda, Nature 294, 670.)

Uematsu, M., Duce, R. A. and Prospero, J. M. 1985. Deposition of atmospheric mineral particles in the North Pacific Ocean. J. of Atmosph. Chem. 3, 123138. 